\title{
Management structure as a factor of performance of Solid Waste Management projects in African municipalities: A case of Bushenyi-Ishaka Municipality, Western Uganda
}

\author{
Kenan Okurut ${ }^{1, a^{*}}$, Moses Nuwamanya ${ }^{2, b}$, Jennifer Isoke ${ }^{1, c}$ and Eleanor Wozei ${ }^{1, d}$ \\ ${ }^{1}$ Department of Engineering and Environment, Faculty of Science and Technology, Uganda Christian University, \\ Mukono, Uganda \\ ${ }^{2}$ District Water Office, Bushenyi District, Uganda \\ akokurut@ucu.ac.ug, ${ }^{\mathrm{b}}$ nuwa1975@gmail.com, ${ }^{\mathrm{a}}$ jenniferisoke@ucu.ac.ug, ${ }^{\mathrm{d}}$ ewozei@ucu.ac.ug
}

\begin{abstract}
Solid waste production is growing exponentially, with stronger trends in developing countries. Uganda is facing rapid urbanization that offers not only new social and economic opportunities, but also more pronounced challenges, including waste management which is not coping with the population growth. Despite the financial support given towards solid waste management (SWM), there appears to be no apparent change. With a population growth of $4.8 \%$ per annum, the Bushenyi municipal waste problem is expected to worsen in future if its management is not taken seriously. This study was aimed at understanding how management structure has influenced the performance of a SWM project in Bushenyi-Ishaka Municipality. A mixed-method approach involving both quantitative and qualitative methods was employed in the study. The quantitative approach focused on counting and classifying features to explain what was observed, while the qualitative method, majorly Focus Group Discussions (FGDs), was used to provide a complete and detailed description of the existing situation in three Divisions of Bushenyi-Ishaka Municipality. The study showed that the project management structure does not provide adequate and equitable representation for each of the participating stakeholders at different levels of the project for the day-to-day activities and supervisory roles. It is evident that low resource input is partly contributing to the $27 \%$ performance of the Solid Waste Management project. SWM should be implemented with a dedicated management structure with adequate and well-skilled personnel for supervision and monitoring. In addition, the budget for municipal solid waste management should be increased to enable the municipal authority to fund the projects effectively.
\end{abstract}

Keywords: Human Resource, Management, Municipality, Performance, Solid waste, Uganda.

\section{Introduction}

As the world continues to urbanize and develop economically, waste production is growing exponentially, with stronger trends in developing countries [1]. In 1999, there were 2.9 billion urban residents who generated about $0.64 \mathrm{~kg}$ per person per day ( 0.68 billion tonnes per year). It is estimated that today these amounts have increased to about 3 billion residents generating $1.2 \mathrm{~kg}$ per person per day (1.3 billion tonnes per year) and by 2025, this will likely increase to 4.3 billion urban residents generating about 2.2 billion tonnes per year [2].

Uganda is facing rapid urbanization (5.1\% per annum) and increasing population $(3.3 \%$ per annum) [3], leading to overcrowding, development of slums, and informal settlements with poor waste management practices. It is anticipated that Uganda's urbanisation will reach a staggering 50\% by the year 2040 [4]. Although urban centres are an inevitable part of development, the scale of 
growth in towns and cities offers not only new social and economic opportunities but also more pronounced challenges. Waste generation in Uganda is between $0.3 \mathrm{~kg} / \mathrm{capita} /$ day for low income earners and $0.66 \mathrm{~kg} / \mathrm{capita} /$ day for high income earners in urban areas [5]. Of concern is that the infrastructure and land use planning including for waste management is not coping with the growth rate [6].

Many interventions have been taken by the state to combat poor waste management; the World Bank Board of Executive Directors approved an International Development Association (IDA) credit of US\$150 million to finance urban infrastructure and improve service delivery in fourteen municipalities in Uganda [7]. Despite the financial support given towards solid waste management, there appears to be no apparent change. It is estimated that less than $50 \%$ of the generated waste reaches the gazetted dumpsite, with the rest dumped in an uncontrolled manner, clogging drains, blocking roads, and occupying undeveloped plots of land in the Municipality [5,8].

In 2008, the then Bushenyi-Ishaka Town Council and the Gemert-Bakel Municipality (the Netherlands) signed a Memorandum of Understanding on solid waste management intended to promote the separation of biodegradable and non-biodegradable waste at household level. Over UGX 150 million was injected in the project, and two separate waste treatment centres were developed in the municipality. Nyaruzinga site was to be used for biodegradable waste, while Kabagarame site would receive non-biodegradable waste.

It is against this background that this research, which was part of a master's dissertation [11], was done to know how management has influenced the performance the SWM project in BushenyiIshaka-Municipality. In this context, management is considered a measure of the leadership and operational structure, while performance is a function of the amount and quality of resources allocated to carry out the services, as well as the socio-economic development and physical characteristics of the service area, expressed mathematically as follows (Eq. 1):

$$
P=f(I, D) \text {. }
$$

Where:

$\mathrm{P}=$ the performance of the service, $\mathrm{I}=$ the resource inputs to the service, and $\mathrm{D}=$ the socio-economic development and physical characteristics of the service area.

In waste management, the desired performance $(\mathbf{P})$ is generally fixed as a future goal, with the estimated level of socio-economic development and physical characteristics of the service area (D), and the level of resources required to achieve the goal (I) at a minimum cost.

In this study, performance indicators focused on certain aspects which are regarded relevant and on which data was readily available. The indicator significance goes beyond that obtained directly from the observed properties. Performance indicators compare factual conditions with a specific set of reference conditions.

\section{Methodology}


A mixed-method approach involving both quantitative and qualitative methods was employed in the study. The quantitative approach focused on counting and classifying features, thus constructing scientific statistical figures to explain what was observed, while the qualitative method, majorly Focus Group Discussions (FGDs) was used to provide a complete, detailed description of the existing situation. The study was conducted in three Divisions of Bushenyi-Ishaka Municipality (formerly known as Bushenyi-Ishaka Town Council - BITC) in south-western Uganda, with a population of 73,353 people in 10,257 households.

The study population included municipal political leaders and employees in BITC (totalling to 135). However, to accommodate other stakeholders of the project, additional twenty five (25) people were purposively selected and included in the study. These were households, business community and representatives of institutions in the Municipality. The collection of data was done through administering questionnaires, conducting oral interviews, focused group discussions, field observations and use of a portable weighing scale carried to measure wastes. For questionnaire interviews, a standard World Bank data collection tool version 1.0 for urban waste management was utilised [12]. This tool was improved to include all areas deemed necessary for the complete assessment of the project. The researchers sought permission from the Municipal Council administration before starting on the project. The scores in assessing performance were organized systematically based on the specific objectives of the study with a scale from 0 to 5 , where a score of zero (0) signifies no capacity or nothing is being done and a score of five (5) shows high capacity. All data collected about project indicators was entered in MS Excel for analysis of the results.

\section{Results and Discussions}

Project management structure: Project management is the job of overseeing a project to ensure it meets its goals, time line and budget. The solid waste management project is under the social services committee of the municipal council that is headed by the secretary of the committee. It is under the Department of Public Health of the municipality headed by the Head of Department who is responsible to the Town Clerk (Fig. 1). The Social Services Committee comprises a Chairman who is elected by the Municipal Council; the Secretary for Social Services and three ex-officio members. 


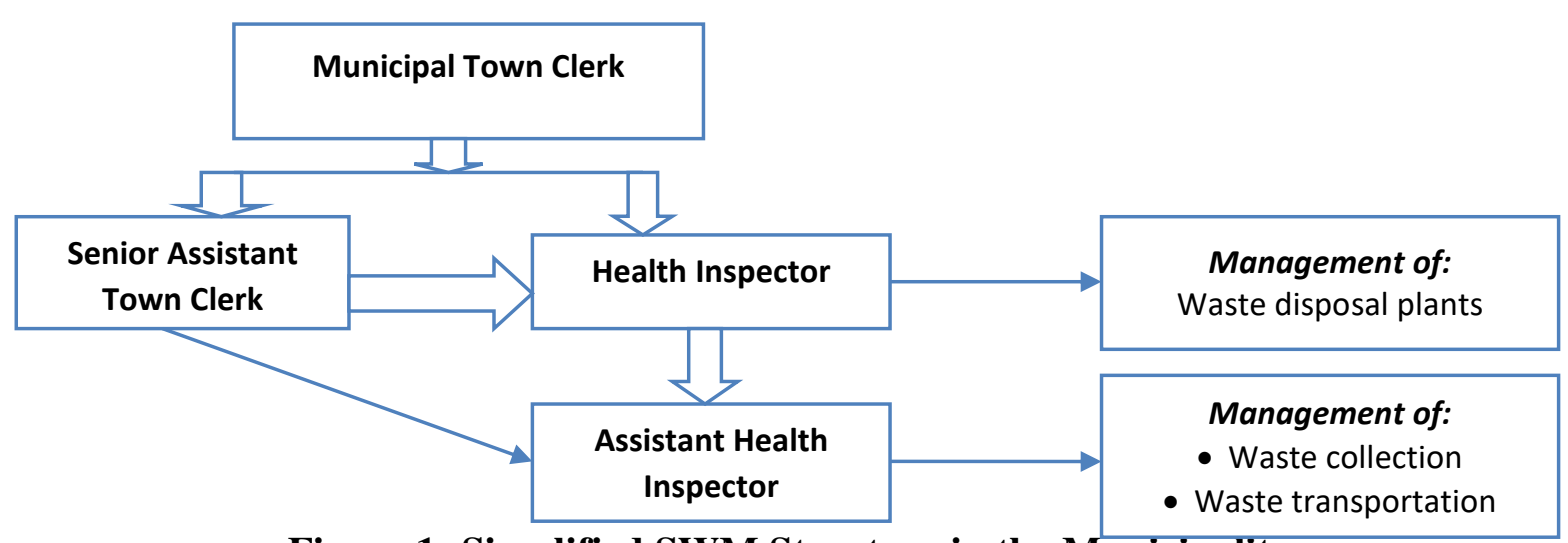

Figure 1: Simplified SWM Structure in the Municipality

The Social Services Committee meets once every three months, but the project does not have a Project Manager, and senior project management members are working in acting capacities. At the municipal level, the Health Inspector, who supervises the management of dumpsite, is responsible to the municipal town clerk while at the division level, waste management is attached to the Assistant Health Inspector, who supervises the collection and transportation of garbage and is responsible to the Senior Assistant Town Clerk (SATC). It is evident that these are added responsibilities to the said officers whose main duties lie in primary healthcare not in municipal waste management. Both office bearers are not qualified in sanitary engineering and cannot offer professional guidance to waste management [13]. The project management structure does not provide equitable representation for each of the participating stakeholders at different levels of the project. The formation of a functional and efficient project team has been, and remains a challenging task for the project management.

There is no organizational chart to show clear lines of reporting. However, in our interview with project personnel, we were informed that they "take instructions from the inspectors." This shed some light as to why the Municipal Health Inspector has little or no knowledge about certain situations in the day-to-day activities of the project.

Human Resource adequacy: Of the 136 approved staff positions in the Council, only 72 posts are filled. Of the 72, the Department of Health and Environment has one Health Inspector and three Health Assistants charged with SWM. These are not adequate even for the supervision that they do, given the growing population of the town and the increasing amounts of waste. It is estimated that the Section responsible for municipal solid waste management required at least 46 staff to efficiently collect, enforce, supervise and dispose of solid waste. Currently only 22 employees are available. This number is not skilled enough to manage solid waste, is shared with other departments, and most of them are unskilled workers. The current project therefore does not have the necessary human resource to run it effectively.

To develop human resources in solid waste management in developing countries, Ogawa [14] further states that three strategically important groups need to be strengthened: Key personnel in the national coordinating unit of the central government; Operational managers of selected local governments; and University and other higher educational institutions. The calibre of field-level 
management is crucial in project sustainability. The projects' ability to engage effectively depends on having mature, experienced personnel who can 'keep their heads' and focus on the strategic goal while responding to the stakeholders [15].

Availability and reliability of records: Effective implementation of waste policies demands an understanding of what has been achieved so far and progress towards future targets. Project data must be found in an enabling environment, clearly kept in project files and analyzed over time. The Municipality has no system in place for regular collection of information in the project area. There are no project offices to deal particularly with project matters, no records about waste amounts and management of waste information in the municipality is a dream. However, waste management activities appear to be monitored, as evidenced by the financial statements obtained from the Municipal Council Treasurer, but there were no progressive project evaluation reports available to back up the statements, and thus determine the project performance trends since project implementation. There were also no activity reports on record that highlight the monthly status of all vehicles, collection schedules, project performance of waste received at the dumpsite, planned activities and staff-related matters.

Occupational Safety and Health Hazard: After the waste has been delivered to the dumpsite, the casual waste workers manually segregate the waste. This work is done in unhygienic conditions and these sorters are vulnerable to pathogenic infections. The staff should be provided with gloves, footwear, apron, masks and goggles for safety as they are constantly exposed to pathogens from waste every day. This is however not the case within Bushenyi municipality.

\section{Project performance}

The project was found to serve $73 \%$ (11) of the Municipal Parishes but only $31 \%$ (25) of the municipal villages are accessing the services. Considering a number of indicators, the project was generally rated to be performing at about $27 \%$ of its expected output (Fig. 2). 


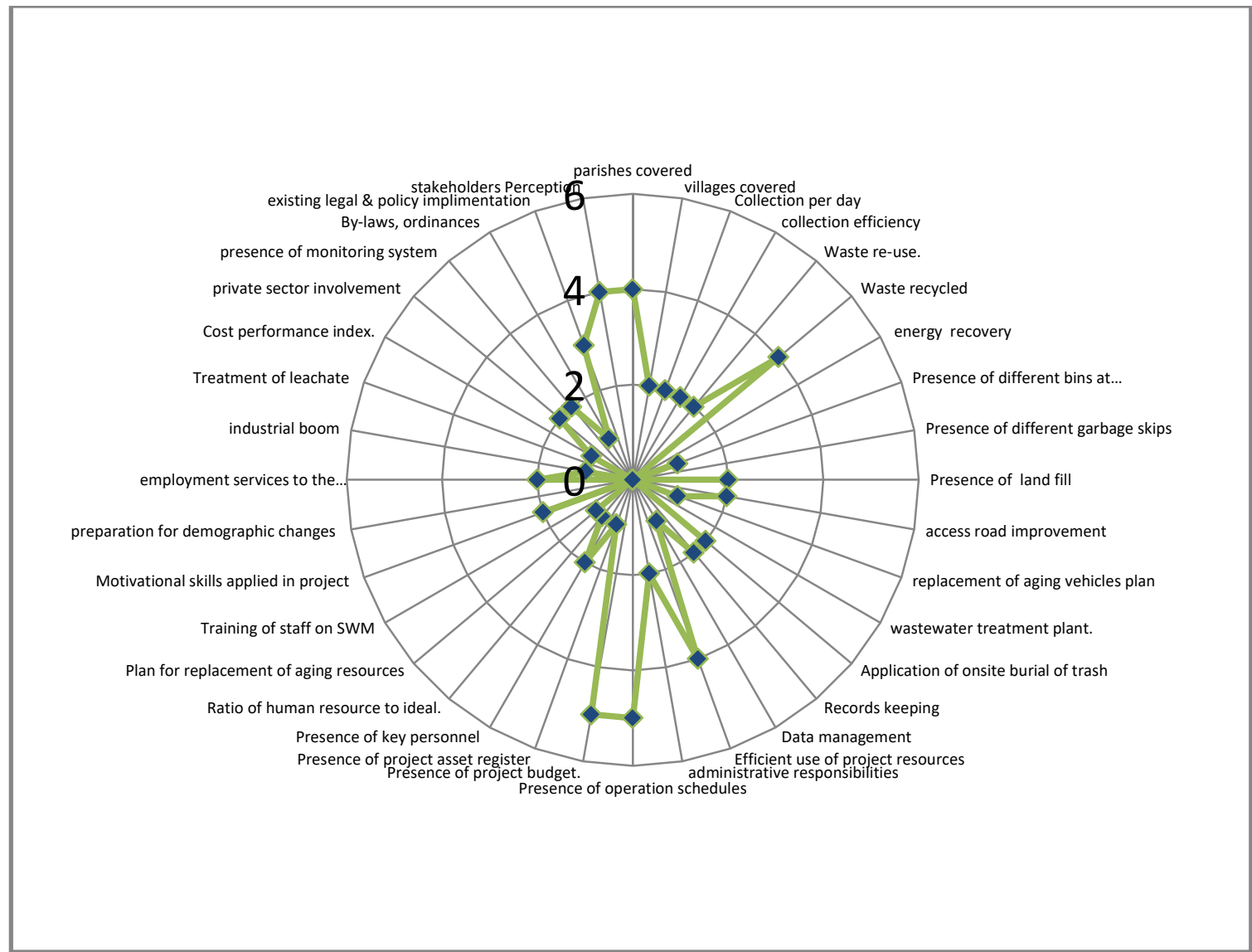

Assessment score $(\%)=((17 * 0)+(13 * 1)+(13 * 2)+(2 * 3)+(3 * 4)+(2 * 5)) *$ $100 / 250=27 \%$

There is virtually no segregation of waste at the source; instead the waste from the municipality is segregated at the dumpsite after collection by the waste truck. Only plastics (11\%) are currently being recovered by a private operator who exports the recovered material to processing plants in Kampala (the capital city). Of the $44,012 \mathrm{~kg}$ of waste generated per day, only $17,312 \mathrm{~kg}$ is collected and taken to the landfill; representing 39.3\% efficiency. Waste collection is done twice in each Municipal Division per week and is limited by inadequate equipment, personnel and financial resources. The Municipality has only one vehicle that makes two rounds each day except Sunday. The collection efficiency of $39.33 \%$ compares with the report from Kawempe Division in Kampala City, in which only $30 \%$ of the solid waste in the Division is collected [3].

Waste recovery and composting would reduce the waste by $66 \%$ of the disposable waste volume. Since the organic fraction is responsible for the pollution by leachate, and methane generation, removal of biodegradable waste from the waste stream to be disposed of in the landfill would reduce the emissions at the dumpsite.

According to existing designs of both the landfill site and the compost plant obtained from the municipal physical planner, as approved in 2009, the sites satisfied both national and international environmental guidelines. However, the project has not implemented most of the infrastructure specified in the design, including tarmacking the access road from the Kasese-Mbarara highway to Kikuuba Trading Centre, incorporating a weighbridge, constructing a culvert for storm water evacuation, water services, electricity, communication utilities, fence against litter and intrusion of 
larger animals and the public, and a landfill liner. In addition, a review of the list of equipment owned by the project as at November 2015 revealed that of the 38 pieces of collection bins, only four were functional.

Uncontrolled unsanitary land filling has been mainly adopted for ultimate disposal of municipal solid waste in the municipality which subsequently can cause health, environmental and aesthetic hazards. The non-treatment of solid waste in the Municipality, is not unique but akin to what happens elsewhere in the developing world, as has also been reported in Kenya where open dumping and burning of waste is the norm [16].

\section{Conclusion and Recommendations}

The study revealed that, proper Solid Waste Management structure are not followed at all; the project management team is not a representative of all stakeholders, roles and responsibilities for each stakeholder are not clearly spelt out. Human resource is not enough and even the existing personnel is not catered for, no training and development for the staff is planned; and it is next to impossible to trace any solid waste project asset register in Bushenyi Municipality.

Limited supervision, monitoring and control have led low coverage of $31 \%$ of the municipal villages and poor performance of $27 \%$ registered by the project. There must be sustainable training of personnel to improve efficiency in the services and municipal authorities must ensure occupational health and safety measures are taken up such as providing safeguard equipment to waste handlers, routine examination to check their health condition and immunization of personnel. In addition, the budget for municipal solid waste management should be increased to enable the municipal authority to fund the project effectively. Project evaluation should be planned to check the performance of the project after every two years.

\section{References}

[1] A.L.E. Courtois, Municipal Solid Waste: turning waste into resource. World Bank, Washinton D.C., (2009) 2-4.

[2] H. Daniel \& B.T. Perinaz, What a waste - A Global Review of Solid Waste Management. World Bank Urban Development Series Knowledge Papers, World Bank, Washinton D.C., (2012) 1116.

[3] WaterAid Uganda, Briefing Paper, Waste, Solid Arrangements, Management Division, Kawempe division, (2011).

[4] E.K. Kyamugambi, Role of engineers in the achievement of Uganda Vision 2040. Kampala, (2014) 5-7.

[5] J. Okot-okumu \& R. Nyenje, 2011. Municipal solid waste management under decentralisation in Uganda. Habitat International, 2011, 35(4), pp.537-543. Available at: http://dx.doi.org/10.1016/j.habitatint.2011.03.003.

[6] P. Mwesigye, J. Mbogoma, J. Nyakang'o \&. Idan Afri Idan, Africa review report on waste management Main Report- Africa (2009). 
[7] IDA, Uganda support to municipal infrastructure program (USMID) (2013) , p.142.

[8] New vision, Sanitation levels in Bushenyi municipality. Kampala: New vision 7 November 2014.

[9] UBOS, National population and housing census 2014 report, Kampala: Uganda Publishers Ltd.

[10] S. Jerie, Analysis of Enterprise Profile and Composition of Solid Waste Generated in the Informal Sector of Gweru, Zimbabwe. Journal of Waste Management Volume 2014, Article ID 865854, pp. 1-2.

[11] M. Nuwagaba, 2017. Assessment of Performance of Solid Waste management Projects in Urban Areas. A Case of Bushenyi-Ishaka Municipality, Department of Engineering and Environement, Uganda Christian University. MSc Disseration, (2017) 44-64.

[12] World Bank, Data Collection Tool for Urban Solid Waste Management - Version 1.0, World Bank, Washinton D.C., (2013).

[13] Ministry of Public Service, 2011. Job descriptions and specifications for jobs in local governments, Ministry of Public Service, Kampala - Uganda (2011). Available at: psmps@publicservice.com.ug.

[14] O. Hisashi, L. M. Kuala, Sustainable Solid Waste Management in Developing Countries, 7th ISWA International Congress and Exhibition, Parallel Session 7, "International Perspective, (1997).

[15] ACF-International Network, 2007. How to make wash projects sustainable and successfully disengage in vulnerable contexts., s.1.: Sarah H ouse, Research Project Manager.

[16] B. Mwanza, \& A. Phiri, 2013. Design of a waste management model using integrated solid waste management: A case of Bulawayo City Council, pp.110-118. 